\title{
Inclusive Financial Services of Microfinance Banks for Inclusive Agricultural Development in Anambra State, Nigeria
}

\author{
Achoja Felix Odemero, Ewuzie Peace Obianujunwa
}

\author{
Department of Agricultural Economics and Extension, Delta State University, Asaba Campus, Nigeria.
}

\begin{abstract}
The study analyzed evaluated the inclusiveness of the financial services of microfinance banks for an inclusive Agricultural development in Anambra state, Nigeria. Secondary data were elicited from three microfinance banks on the number of gender, location and firms that had access to their financial services. The data were analyzed using frequency, tables, mean, and standard deviation, co-efficient of variation, $t$ test and bar chart. The result showed that there are significant imbalances in the financial services rendered by microfinance banks to gender (men and women), location (urban and rural) and firm (non - agro allied and agro allied). The bar chart showed that the degree of imbalances in financial services rendered by microfinance banks is very low in gender, high in location and very high among firms. The result of the test of hypothesis using t-test showed that there is statistical significant difference in the level of financial inclusiveness with respect to locations and firms. We recommended that efforts should be made towards ensuring equity in the degree of financial services rendered by microfinance banks on the basis of locations and firms coveragein order to realize an all-inclusive agricultural development plan in Anambra state, Nigeria.
\end{abstract}

Keywords - Inclusive, financial services, microfinance, banks, agricultural development.

\section{INTRODUCTION}

Despite the poverty reduction efforts made by Nigerian government, inadequate finance services at the grass root remains a major challenge to economic development. A major criticism is that poverty reduction initiative through microfinance were neither participatory nor wellcoordinated at all levels of governance. Whereas the government realizes the need for microenterprise to access financial services through micro finance, there remains a financial service gap in Nigeria.

Although micro-finance institutions (MFIs) are emerging to provide financial services at the grass root level, their outreach is still limited, probably due to underfunding. It is generally observed that most MFIs are weak, fragmented into isolated market segments with little or no connection with the rest commercial banks. The resulting inefficiencies inhibits rural development as relevant micro-enterprises and profitable investments remain largely unfunded and untapped.

As it stands, the majority of the poor households and agro-allied microenterprises, in Nigeria still lack access to sustainable financial services, whether its savings, credit or insurance. Agricultural sector plays cardinal role in Nigerian economic development by providing food security, employment and poverty reduction. Every segment of agricultural production requires the availability of adequate capital since capital determines access to other resources on which farmers depend (Ayoola and Oboh, 2000).

Financial inclusion encompasses improving the range, quality and availability of financial services to the underserved and the financial excluded. It is the process of ensuring access to financial services and timely and adequate credit where needed by vulnerable groups seen as weaker sections and low income groups at an affordable cost (Rangarajan, 2008). It is also defined it as the access to the range of financial services at a reasonable cost for the bankable people and farms (United Nations, 2006). A general broad based financial inclusion is defined as the process of ensuring access to appropriate financial products and services needed by all members of the society in general vulnerable groups in particular at an affordable cost in a fair and transparent manner by mainstream institutional players (Chakrabartty, 2012).

These products and services can be cost effectively provided by a range of financial service providers like microfinance banks. Microfinance is about providing financial services to the poor who are not traditionally served by conventional institutions (CBN, 2005). Financial inclusion implies that both unbanked and underbanked households, rural and urban areas, gender and firms are part of its target market. The focus of financial inclusion at present is confined to ensuring a bare minimum access to a savings bank account without frills, to all.This seminar explores imbalances in inclusive 
financial system of microfinance banks in Onitsha agricultural zone: implications for agricultural transformation.

Agriculture has been described as the engine to economic and social development and growth of a society (Omonona and Agoi; 2007). It employs about $70 \%$ of the labour force and is the base upon which industries revolve. Therefore, if agro allied industries are financially excluded, economic development will elude Nigeria. Women's economic activities at the grass root level in Nigeria revolve around agriculture and other informal sectors (World Bank, 2002). Most of these activities require finance, therefore if women are financially excluded because of lack of collateral, their roles in increasing the economy's productivity cannot be achieved. Also, most rural households and enterprises who work the world's estimated 500 million farms are poor and need access to financial services in order to grow and generate income. The failure of the formal and informal financial sectors to provide affordable financial services to the most disadvantaged portion of the societyis often viewed as one of the main factors that reinforce the vicious circle of economic, social and demographic structures that ultimately cause poverty (Chowdhury, 2005). Hence, the need for an inclusive financial system that will service all clients - firm, gender and location. Some pertinent questions that engage the mind of researchers with respect to inclusive financial system are:(i) what is gender imbalance in financial services rendered by microfinance banks, (ii) what is the degree of location inclusivenessin the financial services of microfinance banks, (iii) what is the degree of firm inclusiveness in the financial services of microfinance banks. Providing answers to the above questions was the basis for the motivation of this study.

The broad objective of the study is to examine the degree of inclusive financial services rendered by microfinance banks in Onitsha agricultural zone: implication for agricultural transformation in Nigeria.

The specific objectives are to;

(i) examine gender imbalance in the inclusive financial services of microfinance banks,

(ii) ascertain location imbalance in the inclusive financial services of microfinance banks,

(iii) determine firm imbalance in the inclusive financial services microfinance banks.

The following hypotheses were formulated and tested to guide the study:

$\mathbf{H}_{\mathbf{0}}$ 1: There is no significant gender imbalance in inclusiveness in the financial services rendered by microfinance banks in the study area
$\mathbf{H}_{0}$ 2: There is no significant location imbalance in inclusiveness in the financial services by rendered microfinance banks in the study area

$\mathbf{H}_{\mathbf{0}}$ 3: There is no significantfirmimbalance in inclusiveness in the financial services rendered by microfinance banks in the study area

Microfinance banks were established to render financial services for economic growth in Nigeria. Whereas previous works examined gender accessibility to microfinance banks credit in Onitsha, Anambra state, Nigeria,the present study examined imbalances in the inclusive financial system of microfinance banks in Onitsha agricultural zone, Anambra state: implication for agricultural development.

\section{LITERATURE REVIEW}

The key dimensions of financial inclusion are;

1. Products- (i) Payments-ATM/debit cards, government, payments, remittance, epayments

ii. Savings/savings account, checking/current account, pensions, youth savings, and program savings.

iii. Insurance (life, health, prosperity, micro-insurance, agriculture)

iv. Credit/personal, consumer, credit card, education, mortgage, home improvement, micro enterprise)

2. Features- (i) Affordability-costs, minimum requirements, fees.

ii. Availability and convenience (days to complete transaction, document required, physical proximity)

iii. Quality- (customer protection including price transparency, fair disclosure, responsible finance practices, risk management and assistance with inclusive credit information systems.

3. Channels- (i) Access points, banking beyond branches

ii. Financial infrastructure-payment and settlement systems, credit reporting, collateral registrations.

iii. Institution- banks/non-banks, insurance companies, pension funds, credit cooperatives, micro financial institutions (MFI's)

iv. Clients-everyone who has the demand for services, including the excluded and underserved poor.

Financial inclusion has gained importance since the early 2000, a result of findings about financial exclusion and its 
direct correlation to poverty. The benefits of financial inclusion are to improve quality of life- Farm families use financial services to gain access to education, health care and other necessities that can improve the quality of life.Make productivity by enhancing investmentEnterprise owner can use credits or savings to make investments in productive assets, such as saving machine, refrigerator or farm implements.

\section{Goals of Agricultural Transformation}

Agriculture has been an engine for economic and social development of a society(Omonona and Agoi; 2007). The goals of Agricultural Transformation Agenda(ATA) with a focus

III. THEORETICAL FRAME WORK

Transmission mechanism of Inclusive Finance for Agricultural Transformation is shown below:

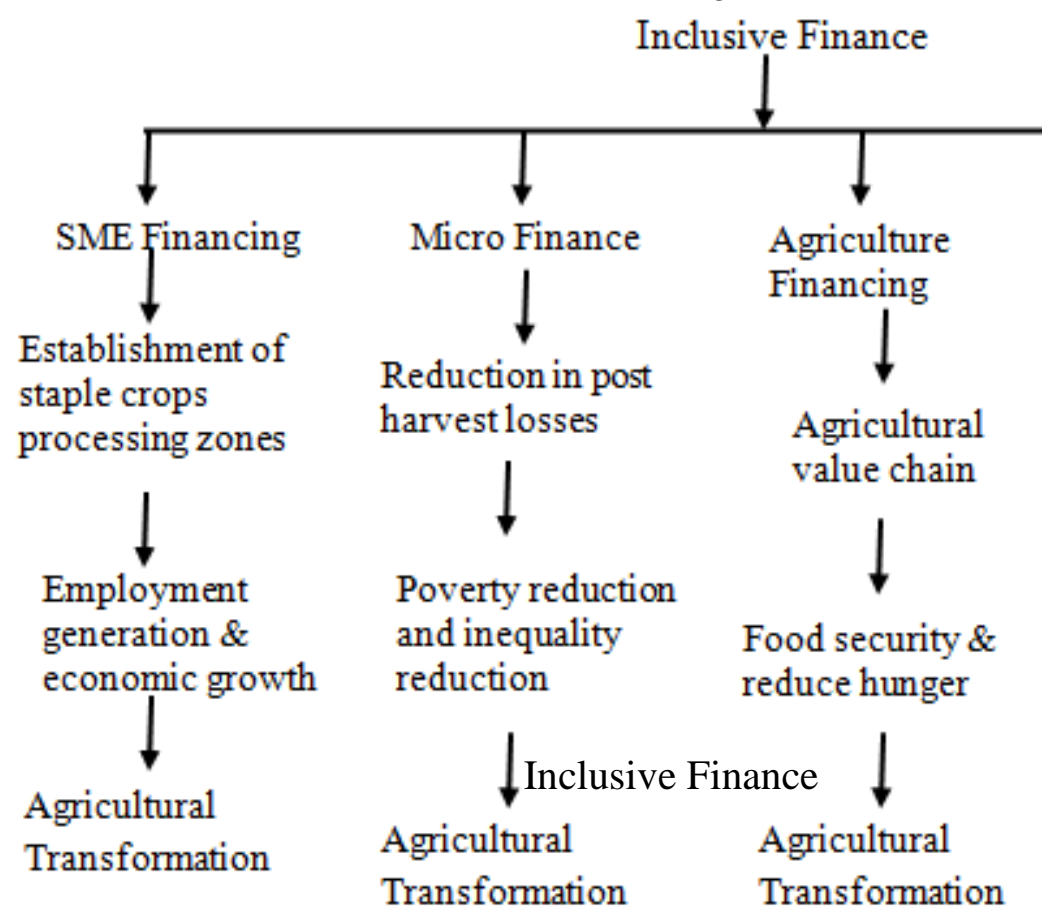

SME Financing Transmission channel: - Flow of SME financing will remove the obstacle of access to finance constraint and create a greater scope to expand business opportunity like establishment of crops processing zones among others. Since SME sector is emerged a key driver for new job creation and economic growth for developing countries. An inclusive financing transmit to agricultural transformation by absorbing extra labour force.

$>$ Microfinance Transmission Channel: Microcredit offers a mechanism for providing collateral free credit to asset less households.Microfinance is regarded as an effective tool to outreach unbanked people in agriculture including women in rural areas who are financially excluded in the formal banking sector for income generating activities which enables reduction in post-harvest losses, reduces
- Development of agricultural value chain, including the provision and availability of improved inputs (seeds and fertilizer), increased productivity and production, as well as the establishment of staple crops processing zones.

- Establishing a sustainable agriculture and agribusiness in Nigeria to raise the income of rural farmers.

The transformation agenda targets rural communities particularly women, youth and farmers association as well as improving rural institutions and infrastructure call for an inclusive financial system. 
through increased productivity and production foragricultural transformation.

$>$ Special Financing for Vulnerable Groups Including Women and Youth Transmission Channel: In this transmission channel, unbanked/underserved people/women/lower income household both in rural and urban areas can access financial services which play a critical part in inclusive development process. Inclusive financial systems allow poor people to smoothen their consumption and insure themselves against economic vulnerabilities, such as illness, accidents, theft and unemployment. Financial access enables poor people to save and to borrow; they can build their assets, invest in education and entrepreneurial ventures, and thus improve their livelihoods. Inclusive finance is especially likely to benefit disadvantaged groups such as women, youth and rural communities for all these reasons, special financing approach has gained prominence in recent years as a policy objective to improve the lives of the poor as well asagricultural transformation.

> Green Financing Transmission Channel: Green financing approach is very important for green growth and sustainable development. Transmission channels and mechanisms between the three pillars i.e. economic, social and environmental are manifold. For instance, economic growth fostered by inclusive policies has positive spill over across economies which in turn leverage social progress. In the same vein growing exposure to vulnerabilities because of poor access to education or lack ofemployment opportunities or poor environmental conditions, negatively impacts economic growth and productivity. Unsustainable consumption and reckless use of natural resources cause environmental degradation and depletion of natural capital, which impacts quality of land and water; loss of biodiversity; and deterioration of ecosystem services. Green financing approach is indispensable for protecting environmental degradation for achieving increased productivity and production foragricultural transformation.

\section{METHODOLGY}

The study was carried out in Onitsha Agricultural Zone, Anambra state, Nigeria. Thestate is divided into four agricultural zones, including Onitsha Zone. These zones are further divided into extension blocks and circles. The study area is suitable for marketing and Agriculture.

The study employed the use of stratified sampling technique in the selection of respondents. From sample frame of eleven microfinance banks in the zone, three were randomly selected and used for the study. Stratified sampling method was adopted because all the microfinance banks have similar features.

The study combined information from primary and secondary sources.Data was collected, basically from the annual records of the selected microfinance banks. Data were based on the characteristics of their clients such as gender, location and firms that received financial services from them.

Simple descriptive statistics(frequency table and charts, mean, standard deviation and coefficient of variation) and inferential statistics ( $\mathrm{t}$ - statistics) were used in analyzing the collected data. The stated hypotheses were tested with the use of t- statistics.

\section{RESULTS AND DISCUSSION}

Table.1: Inclusiveness of Gender, Locations And Firms To Financial Services Rendered By Microfinance Banks.

\begin{tabular}{|c|c|c|c|c|c|c|}
\hline \multirow[t]{2}{*}{ Microfinance Banks } & \multicolumn{2}{|c|}{ Gender } & \multicolumn{2}{|c|}{ Location } & \multicolumn{2}{|l|}{ Firms } \\
\hline & Men & Women & Urban & Rural & $\begin{array}{ll}\text { Non } & \text { Agro } \\
\text { Allied } & \end{array}$ & Agro Allied \\
\hline $\begin{array}{l}\text { Oluchukwu Microfinance } \\
\text { Bank }\end{array}$ & 50 & 20 & 45 & 25 & 50 & 20 \\
\hline Wolilo Microfinance Bank & 35 & 40 & 51 & 24 & 50 & 25 \\
\hline Anya Microfinance Bank & 28 & 40 & 50 & 18 & 52 & 10 \\
\hline TOTAL & 113 & 100 & 146 & 67 & 152 & 55 \\
\hline Mean & 38 & 33 & 49 & 22 & 51 & 18 \\
\hline Standard Deviation & 11.24 & 11.54 & 7.64 & 5.29 & 25.42 & 1.35 \\
\hline Coefficient of variation & \multicolumn{2}{|c|}{$32 \%$} & \multicolumn{2}{|c|}{$22.68 \%$} & \multicolumn{2}{|c|}{$38.79 \%$} \\
\hline t-statistics value (cal.) & \multicolumn{2}{|c|}{0.62} & \multicolumn{2}{|l|}{3.60} & \multicolumn{2}{|l|}{4.01} \\
\hline
\end{tabular}


Table 1 showedthat a total of 213 clientswere served by the three microfinance banks within the period out of the 213,113 were men while 100 were women. In terms of location, out of the total clients of 213,146 were urban while 67 were rural. And in terms of firms, out of the total clients of 213, 152 opereted non agro allied and 55 operated agro allied. This implies that there are imbalances in the financial system of microfinance banks.

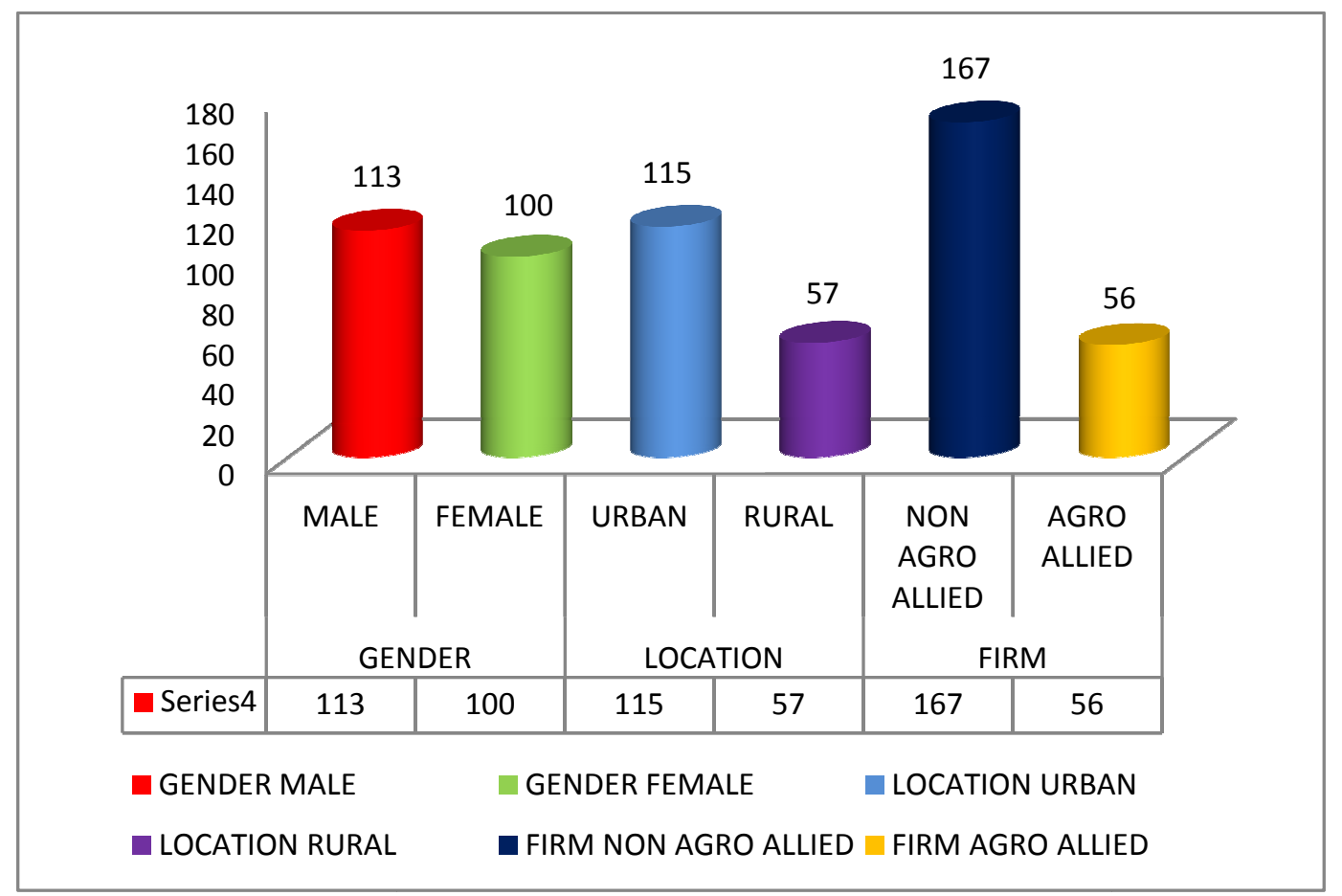

Fig.1: Graphical Distribution of the level of inclusiveness of financial services rendered by microfinance banks on the basis of gender, locations, and firms.

The bar chartin figure 1 showsthe distribution of inclusive financial system of microfinance banks. The result indicates the degree of imbalance is relatively low in gender, high in location and very high in firm.

\section{Test of Research Hypotheses}

$\mathbf{H}_{\mathbf{0}}$ 1: There is no significant gender imbalance in the inclusiveness of financial system rendered by microfinance banks in the study area.

The result in Table 1 shows that the calculated t-value of 0.6 at $5 \%$ level of significance is less than critical value of t-statistics (2.93). The null hypothesis of no significant gender imbalance in the financial services rendered by microfinance banks is accepted and the alternative hypothesis is rejected. Although the coefficient of variation ( $\mathrm{c} . \mathrm{v}=32 \%$ ) and mean value shows that more male clients (38) received financial services than female clients (33), the difference (imbalance) is not significant.This finding indicates that microfinance banks were not gender discriminatory in their financial services. $\mathbf{H}_{\mathbf{0}}$ 2: There is no significant location imbalance in the inclusiveness financial services rendered bymicrofinance banks in the study area.
The test of hypothesis shows that t-calculated is (3.60) greater than t-critical value of (2.93). The null hypothesis is therefore rejected and the alternative which says that there is significant location imbalance in the financial services of micro finance banks is upheld. This result implies that financial services of micro finance banks are biased towards urban location to the detriment of rural area. The rural areas are significantly excluded from the financial services of micro finance banks. The aftermath of this is isolated development. It will encourage drift of resources to the urban area and is capable of widening the development gap between the urban and rural area.

$\mathbf{H}_{\mathbf{0}}$ 3: There is no significantfirmimbalance in the inclusiveness of financial services rendered by microfinancebanks in the study area.

The test of hypothesis shows that t-calculated (4.01) is greater than t-critical value of (2.93). The hypothesis is therefore rejected and the alternative which says that there is significant firm imbalance in the financial services rendered by microfinance banks is upheld. This result implies that financial system of microfinance banks are biased towards non agro allied firm to the detriment of agro allied firm. The non agro allied are significantly excluded from the financial system of microfinance 
banks. This will negatively affect the development of agro allied firm.

\section{CONCLUSION AND RECOMMENDATIONS}

The study showed that imbalances in the financial system of microfinance banks is non-significant among gender, and significant among location (urban and rural) and firm (non- agro allied and agro allied) respectively. Since agriculture is the engine to economic growth and development and employs about $70 \%$ of the labour force, financial exclusion of agro allied firm will have a negative effect on development. The location component of the system is an indication of the extent of coverage of inclusive financial system of microfinance. The present study shows that their services were concentrated in the urban centers at the expense of rural areas that actually need development. The aftermath of this is isolated development. It will encourage drift of resources to the urban area and this is capable of widening the development gap between the urban and rural area. This will hinder the realization of agricultural transformation plan in the study area.

1).The government through the central Bank of Nigeria (CBN) should provide more financial support to microfinance banks sothat its financial system can be more inclusive for agricultural development in the study area.

2). Microfinance banks should ensure higher degree of equity in their financial system in respect to location and firm in the study area.

\section{REFERENCES}

[1] Ayoola G.B., and Oboh V.U.,( 2000), A model of public expenditure to reveal the preferences for agriculture in the budget,Journal of Rural Economic Development.14(1): 56-73.

[2] Central Bank of Nigeria (2005): Microfinance Policy, Regulatory and Supervisory framework for Nigeria. CBN Abuja.

[3] Chakrabarty, K.C. (2011), "Financial Inclusion - A road India needs to travel", Article published in www.livemint.com on sep 21,2011.

[4] Chowdhury, M.J. (2005), 'The impact of microcredit on poverty: evidence from Bangladash'. Progress in Development Studies, 5(4), 298-309.

[5] Omonona, B.T. , \& Agoi, G.A.(2007). Analysis of food security status among Nigeria urban households: evidence from Lagos state, Nigeria. Journal of central European Agriculture. Vol. 8 no.3, pp 397-406.

[6] Rangaranjan,C. (2008), Report of the committee on Financial Inclusion.
[7] United Nation (2006): Building Inclusive Financial Sector for Development.

[8] World Bank (2002): World Development Report Washington D.C

[9] Ugwu, P.O. (2010). Gender Accessibility to Microfinance Banks Credit in Onitsha,Anambra state, Nigeria. Unpublished undergraduate project work, Department of Agricultural Economics, Federal University of Technology Owerri. 